\title{
Judicialization and Health Policy in Colombia: The Implications for
}

\section{Evidence Informed Policy-making.}

\section{Abstract}

The existence of the tutela mechanism and the endemic weaknesses of the legislative and executive branches of the Colombian state have led to a de facto judicialization of health policy-making. The objective of evidence informed policy is to identify effective policy approaches and legitimize policy decisions. Questions arise about the basis on which judges take decisions with significant policy and budgetary consequences, and the forms of evidence they use to inform these. This paper focuses on the extent to which Courts take account of research evidence in judgements and assesses the implications for health policy in Colombia. We place these discussions in the context of a broader analysis of the ongoing reforms to the Colombian health system and the most recent literature on evidence informed policy-making. The judicialization of health policy-making offers a sub-optimal means to achieve the objective of evidence informed policy-making. The emergence of a range of evidence advisory bodies in recent years is an attempt to address the issue of judicialization alongside the other constitutional and political weaknesses Colombia faces. 


\section{Introduction}

The role of scientific evidence in policy-making is a key focus of scholars in the field of health policy. The discourse of evidence-based policymaking (EBPM) reflects moves to understand the causes of social problems more accurately and to develop effective solutions to these (Lavis et al., 2008, Mitton et al., 2007b, Innvaer et al., 2002b, Oliver et al., 2014). At the same time, it speaks to policy makers' need to justify and legitimize their actions, and to ensure an effective use of limited public resources. A now extensive literature exists on EBPM within the field of health policy and beyond, with scholars from Weiss (1979) to Nutley and colleagues (2007) identifying a range of ways in which 'evidence use' or 'research utilization' occur and may be understood.

Perhaps unsurprisingly, debates about EBPM have focused predominantly on the role of the legislative and executive branches of the state, including the role of government bureaucracies, agencies and non-governmental stakeholders (e.g. civil society and nongovernmental organizations, corporations and business associations, professional bodies and activist networks) in the policy-making and legislative processes (Shaxson et al., 2012, see also Contandriopoulos et al., 2010, Innvaer et al., 2002a, Mitton et al., 2007a, Nutley et al., 2007, Walter et al., 2005). However, this legislative/executive nexus is not the only channel through which policy is made in contemporary settings. The judiciary, and judicial activism in sentencing, can have profound implications for the development of policy, which are largely ignored by the EBPM literature. The relevance of empirical evidence for court decisions, particularly in the context of judicial review by constitutional courts, has become a recent focus for legal scholars (Bar-Siman-Tov, 2016), but has received far less attention from political scientists and health policy analysts. 
This article seeks to explore the implications of judicial activism for EBPM making through a case study of the Colombian Constitutional Court (CC) - regarded as one of the most powerful Constitutional Courts in the world (Landau, 2010) - and its impact on the development of health policy in that country. More specifically, it focuses on the use of the tutela mechanism - a protection writ through which any legal person can go before a relevant judge in the Civil, Criminal or Labor Courts and request protection of their constitutional rights (Cepeda-Espinosa, 2004: 552) - by Colombian citizens seeking provision of core health services and treatments. The article builds on the expanding body of scholarship on the judicialization of health policy in Latin America in general (Vargas-Peláez et al., 2014, Gargarella, 2013, Wang, 2013, Menicucci and Machado, 2010, Biehl et al., 2012, Brinks and Forbath, 2014, Daniels et al., 2015, Ferraz, 2009, Figueiredo et al., 2013), and in Colombia more specifically (Uprimny, 2007, Nunes, 2010, Yamin and Parra-Vera, 2009, Yamin and Parra-Vera, 2010, Landau, 2010, González and Durán, 2011, Bernal et al., 2013, Cepeda-Espinosa, 2004).

We argue that while the court system, with the CC at its apex, has played a vital role in the expansion of health care provision to Colombians - guaranteeing their constitutionally determined rights to life and healthcare - the de facto shift of key health policy decisions about the allocation of scarce public resources has significant implications for the goal of EBPM and the drive for efficiency and legitimacy of decision making which underlies it. One response to this would be to shift the locus of decision making back towards the legislative and executive branches in which evidence can more easily be brought to bear on decisions through established processes and practices. While this offers an apparently rationale solution in principle, it fails to take adequate account of the specific problems which have beset Colombian politics, and led the courts to assume their current 
quasi-legislative function. Constitutional weaknesses and widespread corruption have meant successive governments have lacked the political will or capacity to address the issues of health coverage and sustainability. In this context, Colombia has seen a shift towards the 'technocratization' of health policy-making through the outsourcing of key decisions about the allocation of resources to semi-autonomous government agencies tasked with the evaluation and synthesis of relevant evidence for decision making. While this raises questions about democratic accountability, the institutionalization of evidence use in this way offers a potential route out of the current issues associated with judicialized policy-making while reducing the impacts of the constitutional and political weaknesses within the legislative-executive nexus.

\section{Evidence Based to Evidence Informed Policy-making}

This article situates itself in relation to two principle bodies of literature. The first seeks to theorize the role of evidence in the formation of public policy. Given the specific focus of the article on health policy, the discussion of this literature focuses on recent studies of evidence use by health policy makers. The second focuses on processes of judicialization: the increasing involvement of the judiciary in recent decades in the formation and implementation of public policy. Recently, the language of evidence-based policy-making has given way to evidence informed policy-making (EIPM) (see Oxman et al., 2009). This shift in tone recognizes the fundamentally political nature of the policymaking process in which there are multiple, competing values and political priorities at play, often with their own supporting evidence bases (Barnes and Parkhurst, 2014). Advocates of different causes may draw on valid evidence to highlight the need for action on a given issue 
and the effectiveness of specific policy measures in addressing these problems. Policy makers, meanwhile, must decide on which of these issues to prioritize and where to allocate finite resources. They may be presented with multiple bodies of valid evidence about the importance of multiple policy issues, and/or the different effects of a range of interventions and must weigh up which issues to address and the advantages and disadvantages of the different ways to do this (see Hawkins and Parkhurst, 2016). The language of EIPM reflects the increasing recognition that while policy should be made in light of relevant bodies of research evidence, the direction of policy cannot be determined by that evidence. This recalls Deborah Stone's (1997) observation that policy controversies are often debates about values masquerading as facts. However, the logic of EIPM retains a clear emphasis on the importance of evidence use in generating effective, cost-effective and legitimate policies.

Building on the acceptance that policies cannot be derived from evidence alone, Hawkins and Parkhurst (2016) have developed a process based account of evidence use based on the concept of 'good governance'. The good governance of evidence recognizes that policy makers may take decisions which seem to contradict the prevailing evidence base, but this does not necessarily mean that this evidence has been disregarded or ignored, or that this is an example of poor legislative practice. While there may be a sound body of evidence that policy measure $A$ would be effective in tacking issue $X$, there may nevertheless be valid reasons for pursuing another course of action. For example, the policy in question may be of lower political priority (or have lower levels of popular support) than another policy issue which may be addressed instead of, but not as well as, issue X. Alternatively, the externalities from pursuing policy measure A may be so significant that politicians (and the public they represent) may reject them on balance. Perhaps the policy 
would contravene deeply held social values or ethical principles, e.g. personal autonomy or dignity (e.g. the choice to engage in harmful activities such or to refuse medical treatment). It is not difficult to imagine scenarios in which there is evidence for a policy intervention being effective but, nonetheless, rejected because it is seen as morally objectionable (e.g. opposition to clean needle exchange programs), or may have deleterious economic consequences (e.g. significant restrictions on the use of motor vehicles to reduce air pollution).

The good governance of evidence suggests that the decision to reject a given body of evidence is acceptable in such cases, but that policy makers have an obligation to identify and consider relevant bodies of evidence in making their decisions, and to explain and justify their decision to apply or set aside its findings. A 'good' use of evidence, therefore, does not equate to the decision to follow the course of action indicated by a specific body of evidence, but that policy decisions should be taken in light of all relevant bodies of evidence, in an open and transparent manner, acknowledging explicitly the role specific bodies of evidence played in reaching the decision adopted (Hawkins and Parkhurst, 2016). This in turn allows policy decisions, and the evidence on which they are based, to be scrutinized and contested, and policy makers to be held to account for the choices they make.

Analogies with the 'good governance of evidence' can be found in Daniels and Sabin's (2008) 'accountability for reasonableness' framework which attempts to set out procedural guidelines for decision making about the allocation of resources in health systems. This is particularly the case given the application of the good governance framework to the case of Colombia health policy in which the issue of evidence use if closely 
allied to questions of priority setting and resource allocation. However, an important distinction exists between the processes of normative reasoning about the right allocation of finite researches undertaken by Daniels and Sabin and their critics (see for example Friedman, 2008) and the process based account of how evidence may be used to inform policy decisions for this (and other) purposes set out in the good governance framework.

\section{The Judicialization of Politics}

There is now an extensive literature on the judicialization of politics across policymaking domains (Vallinder and Tate, 1995, Ginsburg, 2008, Hirschl, 2008a, Hirschl, 2008b, Hirschl, 2006, Hirschl, 2004) including an expanding sub-literature on this phenomenon in Latin America (Sieder et al., 2005, Rios-Figueroa and Taylor, 2006, Uprimny, 2007, Ryan, 2010, Scribner, 2010, Menicucci and Machado, 2010, Couso et al., 2010, Saavedra-Herrera, 2013, Vale, 2013, Daniels et al., 2015). While it is beyond the scope of this article to review the scholarship in this field exhaustively, it provides important context for the analysis presented here.

More recently, scholars have begun to focus on both the implications of judicialization for evidence use in policymaking and vice versa - the increasing awareness amongst the judiciary about the norms of evidence use in policymaking and the impact this has on their judgements. This is particularly pertinent in the realm of judicial review of legislation. Alemanno (2013) has identified what he terms instead 'an evidence based judicial reflex' in the reasoning of courts engaged in judicial review of government legislation. He coined this term to identify a heightened sensitivity of judges to the increased importance of evidence use in the legislative process and, with this, a willingness 
to strike down laws which have not adhered to established norms of evidence informed policy-making, i.e. where decisions have not been taken in light of the relevant bodies of evidence which the government would be expected to consider.

Bar-Siman-Tov (2016) goes further than Alemanno, highlighting what he terms an increasing move towards 'evidence based judicial review' (EBJR) amongst constitutional courts in various domains across the globe, adding a substantive dimension to the procedural engagement with evidence use identified by Alemanno. Following Alemanno (2013), EBJR may concern the procedures through which a piece of legislation was adopted, and its constitutionality will depend on whether the legislative body adopted the measures in light of relevant evidence and in keeping with established processes of evidence informed policy-making in the domain in question (Bar-Siman-Tov, 2016). However, evidence use is relevant to EBJR in a second, more substantive, way, which implies that judges themselves will evaluate the necessity and merits of the law in light of relevant research evidence. For example, Courts may need to assess the proportionality of the law, if it is necessary for, and is likely to be effective, in achieving its stated objectives, and should base its decisions on empirical evidence (Bar-Siman-Tov, 2016). This implies in turn a research gathering or interpreting role for the court, in which they exercise potentially significant influence over the substantive content of public policy.

This two dimensional conception of evidence use reflects the increasing awareness amongst jurists that rulings of this nature depend on a mixture of normative and empirical judgements which requires recourse to relevant scientific and social scientific knowledge. Niels Petersen (2013), for example, has focused on the specific role of social science evidence in constitutional court rulings. While the US Supreme Court has a long history of using social science evidence in its judgments, this is far less the case in other countries. 
Despite the clear need for social science perspectives to inform judgements, Courts often lack the necessary expertise to evaluate and apply the findings from such research. In this context, judges are faced with three options: they can attempt to interpret social facts on their own, they can defer to the decisions of the legislature as the body best placed to weigh up evidentiary concerns against societal values and political priorities, or they can defer the question to social science experts. In practice, Petersen concludes, none of these strategies will lead to optimal outcomes and judges will need to employ a combination of different strategies. Petersen's contribution links to an associated literature on the deliberative capacity of constitutional courts, and the impact of judicial rulings on the wider democratic process (see Mendes, 2013).

Within different constitutional systems, the judiciary plays widely differing roles, with differing capacities to shape laws and policy. In Colombia, the importance of the CC as a health policy actor emerges in the context of a weak, ineffective government, which has suffered from widespread corruption in addition to its constitutional deficiencies (OECD, 2013, Lizarazo and Londono, 2009). The CC has stepped into this vacuum to tackle crucial policy issues, which the other branches of government have proven unable or unwilling to address (Lizarazo and Londono, 2009, OECD, 2013, Cepeda-Espinosa, 2004). As such, the court has arguably articulated popular demands for health coverage more effectively than the legislative or executive branches of the state, leading to a progressive expansion of healthcare provision (Yamin and Parra-Vera, 2010). However, this has had significant implications on the financial sustainability of the health system, as well as raising concerns about the safety and effectiveness of treatments and equity of service provision (VargasPeláez et al., 2014). Questions of this type are often resolved with recourse to relevant bodies of evidence (e.g. on drug efficacy) to determine which treatments are provided to 
whom and on what basis. The shift away from decision making via the legislative and executive branches towards the judiciary has potentially significant implications for evidence use. Consequently, the process through which the CC reaches its decisions, and the role played by scientific evidence within this, warrants further investigation and consideration.

\section{Methods}

While there is an emerging engagement with questions of evidence use amongst legal scholars, less attention has been paid to these issues in the field of public policy. This article aims to examine the implications of judicialization of health policy-making for the implementation of evidence informed health policy from this perspective. This paper emerges from a six country comparative case study of evidence use in health policy-making in high, middle and low income settings, which examines the processes through which evidence informs policy in different constitutional, political and institutional settings. In each country, we analyze key health policy issues, which offer insights into the role of evidence in decision making at different points of the policy process and in different institutional settings.

As is common practices in the field of policy studies, this article is informed by a nonsystematic literature review on the judicialization of policy-making in Colombia and beyond. Relevant articles were identified via keyword searches in the Web of Science database and via google scholar and snowballing technique was used to identify further articles through the reference lists of the articles identified and later publications citing them. In particular, we sought to identify studies of judicial activism in the area of health policy in Latin America. 
Beyond Colombia, the region has a number of strong constitutional courts, which have exerted significant influence over the policy-making process and thus provide interesting parallels with the Colombian case. The purpose of this was to contextualize our analysis in the relevant bodies of scholarly literature in this area.

In addition, we analysed key policy documents and "grey literature" related to the relevant health systems reforms. Our focus was principally on draft laws before the legislature and those already passed by the Colombian Congress between 1993 and 2014. In addition, we examined relevant documents from various organizations whose remits included healthcare and health provision and which sought to feed into to these policy debates (i.e. Inter-American Development Bank, Defensoría del Pueblo [the Human Rights Ombudsman]). Different publicly available sources, such as the official bulletin of the Congress of the Republic of Colombia and the online archive Congreso Visible were used to search, identify and retrieve relevant draft laws and those already enacted.

We conducted 26 semi-structured interviews with health policy actors ${ }^{1}$ in Bogota in February 2014, including representatives of the main government ministries and agencies with responsibility for health policy-making, and policy advocates including representatives of non-governmental organizations (NGOs) and industry associations. The focus of the interviews was on the use of evidence in health policy-making in general and were tailored to the specific policy area and expertise of the respondent (i.e. if they were a policy maker/ or decision maker versus a civil society advocate). Prior to the fieldwork, we had no

\footnotetext{
1 'Policy actors' is employed in this article as an umbrella term to cover all participants in policy debates and the associated policy-making, implementation and evaluation processes. The terms thus includes policy makers (those in government, or government designated entities, performing key decision making or decision facilitating functions) as well as policy advocates (those outside of government advocating for specific policy objectives.
} 
predetermined focus on specific policy issues or debates. We sought instead to elicit from respondents which areas they believed were the key issues in Colombian health policy; areas in which evidence had been well used to develop policy or conversely areas which would benefit from more effective evidence use and mechanisms to bring evidence into the policy process. As such, the interviews were inductive in nature and interview guides were framed in general issue areas but with scope for follow up and probe questions to explore issues which arose during the interview. These interviews were anonymized, transcribed and analysed using Nvivo software to identify the emergence of key themes. Coding also proceeded inductively and was undertaken by $\mathrm{BH}$, so no issue of inter-coder reliability, although a small number of issues of interpretation arose and were checked with AAR to clarify respondents' intended meaning. All transcripts were initially read to identify key themes which were recorded and used to develop a list of codes (or 'nodes in Nvivo terms) which were used for a systematic analysis of the transcripts in phase 2. During the drafting phase all quotations used were check with AAR to ensure interpretation of the material and the use of the code was appropriate to support the point being made References to the interviews in the current text are also anonymized in keeping with the ethical guidelines for the project, but the sector from which each respondent emerges is given to contextualize their insights and perspective.

\section{The Colombian Health System: A Case of Perpetual Reform}

The current Colombian health system was brought into effect by Law 100/1993, which sought to improve the quality of health service and to address the widespread lack of coverage for large sections of the population which persisted under the previous regime 
(Giedion and Uribe, 2009). Law 100 established a two tier insurance system - a contributory regime for those in employment and a subsidized regime for those without formal employment - centered on multiple private insurers and service providers under a regulated competition model (Escobar et al., 2009, Chernichovsky et al., 2012, Bernal et al., 2012, Glassman et al., 2009). Law 100 also brought into existence a defined package of health benefits (Plan Obligatorio de Salud, POS), which all health insurers must provide. ${ }^{2} \mathrm{An}$ equivalent benefits package for the subsidiary regime was also introduced (Plan Obligatorio de Salud Subsidiario, POSS) (Yamin and Parra-Vera, 2009).

The design of the new health system was highly controversial during the development and passage of Law 100 and contestation over the organization and delivery of healthcare continued after its implementation (González-Rossetti and Bossert, 2000). Agreement on the basic assumptions underpinning the health system has never existed in Colombia and its virtues and deficiencies are widely debated by stakeholders (Defensoria del Pueblo, 2013: 83). According to one commentator, "seismic ideological disagreements" have remained on issues such as the financing of the system (i.e. insurance versus taxation based models); the involvement of the private sector; and whether limits can and should be placed on the right to health care (Author Interview, Health Consultant).

The ideological tensions at the heart of Colombian health policy debates - and the significant challenges posed in providing adequate health coverage in such an economically, geographically and ethnically diverse middle income country with a history of armed conflict - has meant that the health system has faced an almost constant series of reforms since its

\footnotetext{
${ }^{2}$ In this article we use the Spanish acronyms current in policy debates in Colombia. In the text we give both the English and Spanish names of organisations to make the article accessible to as wide an audience as possible and avoid confusion.
} 
inception, which continue to the present day (Bernal et al., 2012, Giedion and Uribe, 2009, Hernández, 2005, Hernández and Torres-Tovar, 2010, Rodríguez Garavito, 2012). However, none of the successive attempts at reform have managed to resolve the underlying weaknesses in the current system or the ensuing ideological debates about its design. Policy debates have centered on two key issues facing the system: the lack of access to effective healthcare, and significant economic pressures faced by the system due to the expansion in service provision (Chernichovsky et al., 2012).

Despite increases in health coverage brought about by Law 100, large sections of the population remain without access to adequate healthcare (Bernal et al., 2012, Giedion and Uribe, 2009). Even those covered by the health insurance system remain unable to access certain services and treatments. In part, this results from the lack of clarity in the definition of the benefits package and the existence of significant grey areas over what treatments are, and are not, included (Yamin and Parra-Vera, 2010). The failure of successive governments to address these issues, along with the extensive rights guaranteed to citizens in the 1991 Constitution, have led many citizens to turn to the Courts in their attempts to secure access to health services. In particular, citizens have had recourse to the tutela process; a protection writ through which citizens are in an attempt to guarantee their constitutional rights, including the right to healthcare (Cepeda-Espinosa, 2004). However, the uneven access to legal services, and the means to pursue tutela actions, has led to greater inequality in access to health services, exacerbating one of the fundamental problems of the system, which successive reform agendas have sought to address. As will be examined below, the significant increase in the use of tutelas to access health services in the 
period from 2000 to $2008^{3}$ has created additional financial pressure on the health system, with significant implications for public finances (Chernichovsky et al., 2012, Rodríguez Garavito, 2012, Uprimny and Durán, 2014). As well as the need to control costs, it has created additional pressure to reform the health system in order to reduce the use of tutelas, and to create more equitable and sustainable mechanisms for allocating resources. At the same time, various decisions by the constitutional court have overruled or struck down proposed reforms, underlining its position as a key veto player in the Colombian political system (Tsebelis, 2002).

\section{Evidence Use in Colombian Health Policy}

The history of health systems reform in Colombia demonstrates that, in the last two decades at least, a clear belief has emerged amongst decision-makers about the importance of EIPM for ensuring efficiency in the health system (Dargent, 2014, Castro, 2014). While not reducible to this sole objective, much of the shift towards EIPM in Colombia is associated with the need to place limits on the health services accessible to citizens and to devise fair and equitable mechanisms for prioritizing the allocation of finite resources.

The various reforms to the health system have introduced a number of mechanisms through which evidence enters in to the formulation of health policy and a range of different institutional structures for generating, processing and operationalizing policy relevant evidence. Many of the recent reforms to the health system have pursued the explicit objective of increasing and improving evidence use in policymaking. Law 1122/2007

\footnotetext{
${ }^{3}$ In this time, the number of tutelas increased by around $570 \%$ (from 24,843 in 2000 to 142,957 in 2008). In addition, the share of tutelas related to health services also increased. While in 1999 the number of tutelas on health represented $18.5 \%$ of all tutelas, this increased to $41.5 \%$ in 2008 . Moreover, between 2000 and 2008 the average growth rate of the number of tutelas per 1,000 affiliates to the health system increased from 1.1 to 3.6 (Ministerio de Salud y Protección Social, 2015; Uprimny \& Durán, 2014; Rodríguez Garavito, 2012).
} 
established the Regulatory Commission for Health (Comisión de Regulación en Salud, CRES); an arm's length body affiliated to the Ministry of Health whose role included updating the POS. However, CRES received considerable criticism from both the media and the academic community due to its apparently inadequate use of evidence and the weakness of methods it employed in evaluating this evidence and reaching its decisions, as well as a lack of transparency in its decision-making processes (Castro, 2014: 22).

The concept of Health Technology Assessment (HTA) was introduced by the government of President Santos in the second half of 2010 as a policy tool to inform coverage decisions on health technologies and the institutionalization of HTA that. The drive to set it up a modern HTA body in Colombia reflected international experience in establishing such bodies. Indeed, a month after the President Santos' election in August 2010, the InterAmerican Development Bank organized a delegation of senior executives from the UK's National Institute of Clinical Excellence (NICE) to Colombia to present the NICE model to Colombian policy makers and stakeholders.

Following the visit by the NICE delegation, the Government set in motion the process of institutionalizing HTA in Colombia. To that end, the government submitted legislation to Congress January 2011. The key focus of the draft law was the sustainability of the Colombian health system, and a key improving the information base and measuring the performance of the system was identified as the key mechanism through which to address this. The resulting Law 1438, which came into effect in September 2012, set up the National Health Observatory (Observatorio Nacional de Salud, ONS), a directorate within the National Institute of Health (Instituto Nacional de Salud, INS) tasked with the generation of evidence to inform health policy and the Institute of Health Technology Assessment (Instituto de Evaluación de Tecnologías Sanitarias, IETS). Modelled on the NICE, IETS was established as a not-for-profit 
public-private partnership (Corporación Sin Ánimo de Lucro, de Participación Mixta y de Carácter Privado under Colombian law). The symmetries between the two organizations are reflected in the appointment Hector Castro - a former project consultant at NICE International - as IETS' first Chief Executive Officer.

The participants in IETS include four public sector actors - the Ministry of Health (MSPS); The National Institute for the Surveillance of Medicines and Food (Instituto Nacional de Vigilancia de Medicamentos y Alimentos, INVIMA); the INS; and the Administrative Department of Science, Technology and Innovation (Departamento Administrativo de Ciencia, Tecnología e Innovación, Colciencias) - and two private sector members - the Colombian Association of Faculties of Medicine (Asociación Colombiana de Facultades de Medicina, ASCOFAME) and the Colombian Association of Scientific Societies (Asociación Colombiana de Sociedades Científicas).

The role of IETS is to provide non-binding recommendations about health technologies and clinical practice. While there are no obligations on government to adhere to IETS' advice, their recommendations carry significant political weight in policymaking. Its initial remit was to undertake health technology assessment in order to inform decisions made by the CRES on the inclusion and exclusion of treatments within the POS. However, only a few months later, in December 2012, the CRES was abolished and the Ministry of Health "re-assumed its role of resource-allocation decision-maker" (Castro 2014: 22; 131). This left IETS with the key task of providing non-binding recommendations to government about health technologies and clinical practice. Assessments of drug safety and market licensing are undertaken by INVIMA. Following the enactment of the National Development Plan 2014-2018 (brought into effect by Law 1753/2015), INVIMA is now responsible for monitoring the potential negative side effects of drugs and can now modify their indications on the basis of relevant scientific 
evidence. This is particularly important in facilitating the access to "off-label" medicines. In addition, IETS is now tasked with undertaking economic (cost/benefit) evaluation of new drugs and medical devices as a prerequisite for obtaining a medical license.

Interview respondents both within, and outside of, government indicated that the Ministry of Health possesses a relatively high level of technical capacity in the generation, interpretation and operationalization of research evidence (Author Interviews; various). In addition, the Ministry, along with other health sector actors, is able to draw on significant capacity and expertise, which exists within universities and research institutes, which undertake knowledge generation and synthesis for the government on a consultancy basis (Author Interview Colombian Academic; Author Interview Pharmaceutical Trade Association). These include: the Research Centre in Social Protection and Health Economics (Centro de Estudios en Protección Social y Economía de la Salud, PROESA, linked to the Universidad Icesi and the Fundación Clínica Valle del Lili); the Centre for Health Economics (Centro Economía Salud, CES, linked to Universidad de Antioquia); the Centre for Research on Development (Centro de Investigación de Desarrollo, CID, and the Universidad Nacional); the Universidad de los Andes; the Centre for Development Projects (Centro de Proyectos para el Desarrollo, CENDEX, at the Universidad Javeriana); and the Centre for Health Studies and Research (Centro de Estudios e Investigación en Salud at the Fundación SantaFe). In addition, the World Bank also has played an important advisory role, supporting the country with technical studies on different health issues including the definition of the health benefits packages, risk assessment, decentralization of health, and the development of health indicators through the funding of projects led by research centers.

Government agencies such as IETS, INS and INVIMA exist for the specific purpose of making decisions on policy issues, which require a high degree of technical proficiency and a 
detailed engagement with a relevant body of evidence. The expansion of these types of agencies across the globe is indicative of the increasingly complex nature of policy-making and regulation, especially in areas of rapid technical advancement such as health. The need for effective, evidence informed policies, and the limited specialist expertise of many elected representatives means decisions are delegated instead to designated specialist agencies. Removing decision-making competence from elected officials implies a loss of democratic oversight over policymaking, but this is often regarded as a price worth paying for more efficient decision-making and more effective policy, leading in turn to greater political legitimacy (Beetham, 2013).

The shift towards the goal of EIPM in Colombia reflects a more general shift towards rationalization of policy-making, which occurred initially in the North American and Western European contexts, in the search for more effective and efficient policy interventions. The issues of effective and cost control are closely connected. It was hoped that 'better' (more effective/ efficient) policy would also be more cost effective, producing the greatest possible impact from the resources available. In addition, the emergence of EIPM reflects the search for new sources of legitimacy for policies in the context of the declining authority of government, professional bodies and individual expertise. In the context of health policy, this involved an implicit rejection of the authority of individual physicians and their autonomy over clinical decisions, which were to be guided instead by 'the best available external clinical evidence from systematic research' (Sackett et al., 1996). In Colombia, doctors, via their national trade association, perceived the shift towards EIPM, and the institutionalization of HTA, with a degree of suspicion given its potential to curtail their professional autonomy and their 'freedom to prescribe' (see Present Authors, under review). As will be discussed below, the expansionist rulings of the Courts demanding the provision of medical treatments prescribed to patients but denied by insurance providers - along with the weight placed by the 
courts on the testimony of the attending physicians - has served to buttress the position of doctors in the wider power dynamics of Colombian health policy debates.

\section{The "Judicialization" of Health Policy in Colombia}

The Colombian judiciary is divided into a number of specialized sections, with the three principle jurisdictions each headed by a specific court of last instance (Cepeda-Espinosa, 2004). ${ }^{4}$ The "administrative jurisdiction" resolves conflicts derived from the exercise of public administrative powers and is headed by the Council of State. The "ordinary jurisdiction" hears cases in the areas of civil, criminal and labor law and is headed by the Supreme Court of Justice, which presides over two other levels of court: municipal and circuit courts (courts of first instance), and district courts (second instance). A tutela action can be started at any municipal court. Finally, the "constitutional jurisdiction" is headed by the CC which is the highest judicial body in Colombia.

The CC is given three principle responsibilities under the 1991 Constitution: (i) interpreting and preserving the integrity of the 1991 Constitution; (ii) safeguarding the rights of all citizens; (iii) maintaining a progressive, peaceful and fair society as envisioned during the formulation of the Constitution (Cepeda-Espinosa, 2004). In practice, the CC acts as the court of last instance in matters affecting the constitutional rights and obligations and reviews the constitutional validity of decisions taken in lower courts, as well as the constitutional compatibility of legislation and other executive decisions. In the case of tutelas, the CC reviews selected cases adjudicated by judges in lower courts.

\footnotetext{
${ }^{4}$ The "disciplinary" jurisdiction is in charge of the branches' organization and budget administration and disciplinary actions. It is headed by the Superior Council of the Judiciary. In addition, there are the special military criminal jurisdiction, the indigenous jurisdiction, and "judges of peace" (private citizens granted specific judicial powers by the Constitution and the law in minor cases)" (Cepeda-Espinosa, 2004).
} 
Despite the attempts to rationalize and improve resource allocation through the reforms detailed above, problems of access to health services and the economic sustainability of the health system continue to endure. Both the legislative and executive branches of the state have proved ineffective in addressing these issues. Under its 1991 constitution, Colombia has suffered from endemic weaknesses of both the legislative and executive branches of the state, resulting in an absence of effective policy responses to a range of pressing social issues. The weak, unstructured party system (Landau, 2010: 341, Leongomez, 2006), and endemic corruption amongst parliamentarians (Landau, 2010: 342, López and Sevillano, 2008) and a history of authoritarianism and political violence (Yamin and Parra-Vera, 2009: 147), has contributed to Congress' consistent failure to perform its constitutionally mandated functions of initiating and enacting effective legislation, and holding the Executive to account (Landau, 2010: 362). Thus the legislature has failed to act as an effective mechanism through which citizens can articulate dissatisfactions with the health system and through which their needs and interests can be articulated, with Congress acting more as a veto-player (Tsebelis, 2002), stymying presidential policy initiatives rather than as an effective agent of policy change (Leongomez, 2006). Yamin and Parra Vera (2010) cite the process through which Law 100 itself was passed - in curtailed parliamentary debates lasting a matter of minutes, shoehorned into the legislative programme immediately before Christmas - as indicative of the inadequacy of Congress as a mechanism capable of responding to citizens' concerns or as a focus for articulating popular concerns on key issues of public policy. Subsequent attempts to reform the health system between 2003 and 2007 have demonstrated similar deficiencies in the system (Bernal et al., 2012). 
Within this political vacuum, the court system, with the CC at its apex, has emerged as perhaps the most important policy set of actors in the Colombian political system (Author Interviews, Colombian Academic; Human Rights Ombudsman). David Landau (2010: 322) argues that the $\mathrm{CC}$ has viewed the political conditions in Colombia "as a license to become perhaps the most activist court in the world." At times, the court has performed a quasilegislative role "injecting policy into the system, by managing highly complex, polycentric policy issues and by developing a thick construct of constitutional rights that it uses to check executive power" (Landau, 2010: 321). In so doing, the legislature has become a far more effective agent for political change, and reflecting popular will more closely, than the other branches of the state to which this function traditionally belongs (Landau, 2010: 328, Yamin and Parra-Vera, 2009).

The principal mechanism through which the $\mathrm{CC}$ has been able to expand its remit into areas which are usually the preserve of parliaments has been via the tutela process. While the constitution did not establish the right to health as a first order constitutional right, the jurisprudence of the court has expanded the right to health services in relation to the right to life. The CC held that cases in which the lack of access to health care treatment or drugs could endanger the life of the individual, constituted an indirect infringement of the right to life. Judges are required to give priority attention to tutela actions over other business before the court and pass judgement on the case within 10 days. In addition, judges can take preliminary decisions to prevent irreversible damage occurring to plaintiffs. As such, tutelas provide citizens with a quick, efficient, inexpensive and effective means of guaranteeing access to health services. The importance of the tutela process in the Colombian context, is underlined by the much higher number of processes brought in 
Colombia than in other countries (e.g. Mexico) with a similar level of economic development or comparable level of judicial activism (Rodríguez Garavito, 2012: 519).

The tutela process created a mechanism through which patients could seek to obtain treatments prescribed by doctors, but excluded from the POS. The effect of this was to expand the range of treatments, drugs and services within the POS (Yamin and Parra-Vera, 2009: 147), with clear financial implications for the health system. The Ministry of Health (2015) has estimated that around $37.5 \%$ of tutela cases involved attempts to access treatments excluded from the POS. Additional cases (0.5\%) centered on demands for branded pharmaceuticals instead of generic equivalents included within the POS. Given the reliance of policy makers on scientific and technical expertise in deciding the content of the POS, it is these cases which are of most obvious relevance for the present focus on evidence use in the context of judicialized forms of policy-making. The overwhelming majority of judgements in tutelas on health are decided in favor of the patient (Rodríguez Garavito, 2012: 527). The Office of the Human Rights Ombudsman estimated in 2007 that over $80 \%$ of cases brought forward by patients were upheld by the CC (Defensoria del Pueblo, 2013). This has led to increased access to a range of services and treatments including provision of cancer and anti-retroviral drugs and covering the cost of treatment of patients overseas (Yamin and Parra-Vera, 2009: 148). From this perspective, the court is viewed as a key driver of progressive social change (Author Interview, NGO Sector).

The increase in treatment provision brought about through the tutela process has had significant implications for public spending and the financial sustainability of the health system. The system of recovery (recobros) meant that in many cases health insurers were able to pass the costs of treatments provided via tutelas onto the central government. CC judgement SU-480/1998 allowed health insurers (EPS) to recover the costs of treatments 
prescribed by a doctor, but not included in the POS, from the government's Solidarity and Guarantee Fund (FOSYGA). The tendency of judges to find in favor of patients in tutela actions has led to significant increases in the provision of health services and treatments not included in the POS. Since Judgement T-760/2008, the number of treatments and medicines not included in the POS has risen significantly. According to official estimates, the recobros for these treatments increased from COP\$ 600 billion in 2007 (US\$200 million) to COP\$2.4 trillion in 2010 (US\$ 800 million). Since these costs have to be covered with public finances, this increase placed significant pressure on the financial sustainability of the health system (Fedesarollo, 2012). Between 2005 and 2010, 54\% of the recobros requests were due to tutelas (Ministerio de Salud y Protección Social, 2015). However, more recently this percentage has decreased. Between 2009 and 2014 on average 21\% of recobros were associated with tutelas/court orders (Ministerio de Salud y Protección Social, 2015).

Successive governments have sought to address the consequences of this judicialisation of health policy, and to reduce the number of tutela actions, through various reforms. Law 1122/2007 sought to counter the expanding costs of healthcare through the introduction of Scientific and Technical Committees (CTCs) within the health insurers to evaluate requests for treatment from patients which are excluded from the POS. Where treatment is denied by the CTC, patients still had recourse to the tutela process, but the CTCS created an additional mechanism to resolve disputes about service provision without recourse to the courts. The introduction of CTCs represented an attempt by the Government to control the increasing costs associated with the expanding package of benefits. In those cases in which the relevant CTC had denied access to a specific treatment, procedure or drug, and the patient subsequently brought a successful tutela action to secure its provision, the EPS could only claim back $50 \%$ of the cost of the treatment, procedure or drug from the 
government, as opposed to the full amount recoverable if approved by the CTC. Despite its intentions, Law $1122 / 2007$ created an incentive for insurers to authorize all treatments requested by patients via the CTC, and thus failed to control health spending costs. While in $200960 \%$ of recobros requested were due to CTC authorizations, by 2014 this share had jumped to 88\% (Ministerio de Salud y Protección Social, 2015). Consequently, in April 2016 the Ministry of Health decided to scrap the CTC, replacing them with an online system in which doctors have to report and explain the reasons for all prescriptions of treatments not included in the POS. The online database is designed to streamline the authorization processes for treatments, which previously took several weeks. In addition, the database will be used to monitor doctors' prescribing patterns and censure those who unnecessarily prescribe high-cost treatments excluded from the POS.

The period since 2008 has seen further attempts by both the government and the CC to adopt a "structural approach" to the right to health, with the aim of "de-judicializing" health care provision (Rodríguez Garavito, 2012). Judgement T-760/2008 introduced a new mechanism - "Complex Orders" (Órdenes Complejas) - in an attempt to orientate the judgements of lower courts through a structured route rather than on a case-by-case (casuist) basis. This same period has seen ongoing attempts to reform the health system, with the dual aims of increasing access to healthcare and ensuring the financial sustainability of the system. However, attempts to place limits on health spending by placing limits on the package of benefits available to citizens have been consistently thwarted by the $\mathrm{CC}$ and its tendency to rule in favor of plaintiffs' right to health.

\section{Evidence Use in a Judicialized Health System}


From the preceding discussion, it is clear that the courts play a vital role in health policy-making in Colombia, determining the range of treatments and health services available to patients with significant budgetary implications. The de facto delegation of vital policy decisions to the courts raises important questions for evidence informed policymaking. These relate to the ability and the disposition of judges to take into account relevant bodies of evidence on the effectiveness and cost effectiveness of treatments when ruling on their provision from public funds. Moreover, it concerns the extent to which judges (should) consider the broader political implications of their rulings, for example the sustainability of the health system and the implications of expanding health care costs for other areas of public policy.

Judges, particularly in the lower courts, often lack dedicated resources, technical capacity and specialist training on the wide range of issues with which they are confronted (Bernal et al., 2013). In these cases, decisions are often based simply upon the opinion of the prescribing doctor that the treatment in question was medically necessary. According to a former employee of the Ministry of Health, judges often rely on the prescribing doctors' interpretations of the current state of medical knowledge about the treatment in question, with evidence supplied to the court by the doctors in question to support their initial decision (Author Interview, former Ministry of Health employee):

For example, a doctor might have prescribed a medication that is not licensed in the country. The health care system regulation is clear that this type of drug cannot be covered, so the health insurer denies the patients access to it. Some patients would start a tutela action to get access to the prescribed drug, with the judge ruling in favor of the patient, ordering the insurer to import and provide the drug, using as evidence just the prescription and a summary written 
by the doctor where he states that the drug is needed and that [denying the drug] poses a threat to the patients' health.

The reliance on the opinion of prescribing physicians assumes that their clinical decisions are grounded in sound evidence about the effectiveness and safety of the treatments they are administering in a context in which doctors vehemently defend their "freedom to prescribe" (Author Interview, GJM). Moreover, this approach seems to undermine the organizations and mechanism put in place to undertake independent reviews of this evidence and approve medications for specific indications (i.e. INVIMA). As many tutelas involve the refusal of health insurers to provide medication or services prescribed by physicians, the tendency for judges to defer to individual clinicians in this way partly explains why such a high percentage of tutela judgements rule in favor of the plaintiff. This has led to expansion in coverage, but also to significant additional costs of the health system. This potentially results in a sub-optimal use of health system resources through ineffective prescribing practices and may result in patients receiving inappropriate treatment.

The Justices of the CC who review tutela actions do have mechanisms available to them through which to consult with experts, public officials and organizations before resolving, in order to "bring facts and conflicting perceptions of social reality to the Court's attention" (Cepeda-Espinosa 2004: 556). The CC's decision-making process thus brings the opportunity to present and incorporate relevant evidence within the decision-making process of the court. However, the way in which the CC appraises evidence is often problematic nonetheless, suffering from similar deficiencies as the lower order courts. A former employee of the Ministry of Health cites the case of a woman denied access to a drug for treating 
chronic cystitis because it was not yet licensed in the country (Author Interview; see also judgement T-945/2004):

In the court of first instance, the judge ruled against the patient on the basis that the regulations were clear that providing this type of drug is not allowed. The CC selected this tutela for review and changed the ruling in favor of the patient. The CC argues that the doctor that prescribed this drug used the best available evidence, thus it sees the doctor himself as representing the highest level of evidence. The CC court says that drugs should be provided when they are required based on the best available evidence even if they have not been licensed. Regulatory agencies have been set up to protect the population by allowing only drugs and devices that can show their safety, efficacy and quality to enter the market, and having someone accountable for its commercial use. These agencies - in the case of Colombia it is INVIMA - have standardized procedures for the critical appraisal of the evidence presented by the producer to grant market access to ensure that benefits exceed the risk, thus using high quality evidence to support its decision.

This is not an isolated case. For example, in case T-975/1999, the CC again sided with the evidence of the attending doctor, having heard evidence from a range of relevant medical organizations and scholars. This went against the decision of the lower courts to deny treatment on the grounds that the treatment in question had not been approved by INVIMA.

In these cases, the CC appears not to distinguish adequately between different types of evidence, placing significant faith in the interpretation of the prescribing doctor. As in other countries (see for example Baggot 2007), doctor's specialist expertise, high social status, political contacts and strong representative organizations have granted Colombian physicians significant influence over health policy. In keeping with this, the GJM, which defends the professional autonomy of prescribing doctors, enjoys significant political 
influence as the combined voice of the entire Colombian medical establishment. This reflects a tendency by the court to assume that the attending physician has the best overall understanding of the case at hand and to privilege their opinion over that of the key institutions in the evidence advisory system. While this may be true in terms of the clinical history and the particular circumstances of the patient in question, it does not follow from this that the doctor is best placed to judge the effectiveness and/or safety of the drugs in questions, or their appropriateness for off label usage. Yet judgements about the safety and efficacy of a drug reached through a critical appraisal by the designated regulatory authority, INVIMA, are often overruled by the courts.

The preceding discussion underlines that the judiciary is informed by a very different set of norms and priorities to the legislative and executive branches. Within the CC, for example, justices act to guarantee individual rights in specific cases through its interpretation of the constitution, but it is beyond the court's remit or competence to take into consideration the wider implications of a ruling on the health system or the allocation of resources within society. This includes the willingness to overrule limits placed on treatments by the government. In case T-945/2004, for example, the CC is very clear about the priority of fundamental rights over what it terms 'legal or administrative regulations' which may undermine these rights. The court is ill placed to take complex political decisions between competing needs and imperatives in the context of limited resources. However, the cumulative effect of its rulings on individual cases has long term distributive effects (Yamin, 2014). This reflects findings about the ability of activist courts in the US context to make effective social policies (Horowitz, 1977a) and, in particular, their ability to process relevant facts and different forms of evidence related to the resolution of these complex issue (Horowitz, 1977b). The above analysis is also in keeping with the findings of Vargas-Pelaez 
and colleagues (2014) that judicialized forms of decision-making on access to medicines can lead to a suboptimal use of resources and create significant financial pressure on the health system.

\section{Addressing the Consequences of Judicialized Health Policy-making}

According to Landau (2010: 344), the CC is aware of the quasi-legislative role it has come to assume under the 1991 constitution and has sought to increase the legitimacy by "assuming some legislative-like attributes", including the information-gathering and monitoring functions usually assumed by legislatures. The wide range of cases brought before the CC via the tutela process means the court is confronted with information on a wide range of social issues affecting Colombian society. The $\mathrm{CC}$ has also engaged extensively with the Human Rights Ombudsman, and other civil society groups and NGOs, in order to gather and assess information in important policy areas (Landau, 2010: 344). The Court has used a variety of techniques to gather policy-relevant information in order to assess the constitutional compatibility of different legislative measures, including issuing orders to request information from the various governmental and non-governmental agencies, particularly about how much money they are spending on the problem and how they are spending it (Landau, 2010: 360). Perhaps most notably from the perspective of the current paper, the CC has also held its own legislative-style hearings:

In July 1999, the Court held a public hearing on the issue of reforming housing finance system in the style of a legislative committee or an administrative agency, in which it heard from about twenty-five leaders and officials, including the Colombian ombudsman, the Minister of Housing, the Head of the Colombian Central Bank, several deputies and senators, the heads of various trade groups, and the head of a labor union association. In addition, 
throughout the process the Court requested-and received-written comments on the problem at issue from an extraordinary number of figures, including economists, academics, public officials, and civil society groups (Landau 2010: 357).

Yamin and Parra Vera (2010) highlight that the actions of the courts in attempting to ensure the right to health has had the effect of promoting debate about the right to health in Colombia and have thus provided much of the impetus for the proposed reforms to the system, including the institutionalization of evidence use detailed above. At the same time, it has tried to create greater coherence and consistency in its own jurisprudence, for example through ruling T-760/2008 which sought to clarify the outer limits of the right to health services and " to make those grey zones [in the POS] less grey" (Yamin and ParraVera, 2010: 113).

Since 2012 the government has taken a number of steps to increase access to healthcare. In addition to abolishing CTCs and the reforms to the INVIMA discussed above, the Ministry of Health has periodically updated the contents of the POS and has sought to improve understanding within the medical community about precisely which treatments it contains. In addition, more resources have been allocated in order to increase the supply of health services in rural areas and outside of the main cities, and remotely accessible medical services ('telemedicine') are being promoted. Moreover, a new healthcare model (known as MIAS), based on the idea of comprehensive health risk management and the recent evidence, has been implemented since 2014. The government also liquidated two of the largest health insurers, Saludcoop and Caprecom, which had been associated with serious problems concerning access to healthcare services. 
Despite these developments, the question remains whether the mechanisms put in place by the CC are sufficient to ensure that effective, evidence informed public policies are made. Setting aside the wider concerns about the democratic accountability and legitimacy associated with judicial activism of the kind engaged in by the $\mathrm{CC}$, it can be argued that legislating through the judiciary in this way represents a sub-optimal form of policy-making. In principle, the processes and mechanisms which exist within the legislative/ executive domain provide more appropriate conditions for the development of legitimate, evidenceinformed policies in which the interests of citizens can be aggregated, and competing calls of resources weighed up against one another in light of evidence about the impact of each policy problem and the effective ness of proposed responses. The current state of affairs in Colombia, in which the courts have assumed this quasi legislative function, has emerged as a result of the structural weaknesses and extensive corruption within both the legislative and the executive. It is also crucial to highlight that many tutela cases do not arrive at the $\mathrm{CC}$ for adjudication, but have significant consequences for the health system. Issues around the effectiveness of evidence in lower order courts are not affected by reform processes in the CC.

To fully examine the implications of judicialization of policy-making for the use of evidence, it is informative to return to the concept of the 'good governance' of evidence set out above and to assess the extent to which the judicialized policy-making model in Colombia fulfils this. The good governance of evidence model suggests that EIPM should be assessed in terms of the appropriateness of the evidence used to inform decisions, the transparency of the decision-making process and the contestability of decisions, and should hold decision makers to account. 
These criteria envisage a parliamentary model of decision-making in which elected assemblies serve as a mechanism through which citizens are able to hold legislators and the executive to account, and which function as a point of contestation for policy decisions. In Colombia, Congress has consistently failed to fulfil this function, with the CC emerging not just as an agent for policy change, but as a focus for the articulation of popular needs and desires. Yet despite the legitimacy of the $\mathrm{CC}$ in the eyes of many citizens, the CC lacks mechanisms of popular control and oversight. There is no obvious form of recourse by which judges can be held to account for their decisions or by which a system that systematically favors the interests of those with access to legal means of redress can be curtailed and reformed to reflect principles of fairness and equity. As we have seen above, it has proved extremely difficult for the government to reverse decisions or to introduce changes to the allocation of health benefits in the face of contradictory CC rulings.

In addition, the types of evidence used by judges are not necessarily the most appropriate, relying for example on the view of a prescribing doctor over the overall body of evidence on the efficacy and cost effectiveness of the drug. The CC has taken measures to improve evidence use by holding public hearings, but its structures are not designed to undertake the kind of evidence review which policy bureaucracies and parliaments can undertake. Similarly, while the recent decisions made by the CC have sought to create more consistency in sentencing and to set some limits on the constitutional right to health, the Court is not designed to evaluate the competing claims of different social groups to finite resources. This type of deliberative, evidence informed debate can occur much more effectively in parliamentary settings which facilitate citizen engagement and oversight. Instead judges have tended to rule on the validity of claims to a certain treatment in isolation from broader concerns about the public interests and the sustainability of public 
finances. As such they are not taking into account all the relevant evidence for the decisions they are taking which are framed in very different terms by jurists than they would be by policy makers who have to take a wider conception of the public good.

The conclusion that the legislative-executive nexus represents a more appropriate set of institutional structures to make evidence informed policy than courts must, however, acknowledge that this is not always the case in practice. In Colombia, for example structural and constitutional weaknesses, allied with political corruption, have meant the parliament and the executive have failed to perform these legislative functions effectively, with the courts stepping into this vacuum to resolve pressing health care issues. In this context, any moves to curtail the quasi-judicial role must acknowledge the conditions in which this emerged and look to address the more fundamental issues in the political system, which brought this about. The moves towards technocratic forms of decision making, in the form on institutions such as CRES and IETS, represent an attempt to shift policy decisions away from the courts into structures more adequately designed for this purpose, whose legitimacy is derived from the evidence on which their decisions are based.

\section{Conclusion}

The judiciary, with the CC at its apex, plays a vital role in the development of health policy in Colombia with significant consequences both for the provision of health services and for public spending. To a large extent, this reflects the shortcomings of the executive and legislative in providing effective responses to key policy problems identified by citizens. Within a context of finite resources, and a constitutionally guaranteed right to health services (pertaining to the right to life), this raises important issues of equity and social 
justice. Can limits be placed on the provision of health benefits which are in keeping with the fundamental tenets of the constitution? If limits are to be placed on the availability of health services, on what basis should these decisions be made and how can they be justified to the citizens affected by them?

Within modern forms of government, recourse is often made to scientific evidence to arbitrate in such cases. The shift towards evidence informed policymaking, or at least a rhetorical commitment to it, is driven by a desire for more effective and efficient policies but reflects also the need for governments to find widely accepted sources of legitimacy for their decisions. Relevant bodies of evidence may clarify both the effectiveness and cost effectiveness of specific treatments, in isolation and in relation to other treatments which could potentially be funded from the same pot of money. The development of the evidence advisory systems is designed to provide policy makers with relevant, high-quality information on which to base their decisions. As in Colombia, governments may put in place specialist regulatory agencies, or call on panels of experts, to examine this evidence and advise decision makers. At other times, decisions on the provision of specific treatments or their inclusion in the benefits package may be delegated to non-governmental or quasi-nongovernmental agencies.

Debates about the role of evidence in policy-making have largely neglected the role of the judiciary in the development of law and policy. In cases such as Colombia, in which an activist constitutional court has had a significant impact on health and public policy, this represents a significant gap in our understanding of the way evidence shapes policy. This paper begins the process of addressing that gap by examining the role of the judiciary, and the CC more specifically, in the development of Colombian health policy. In so doing it raises 
questions about the relationship between the executive, legislative and the judiciary, and the role of evidence in the execution of their responsibilities. It appears to be extremely difficult to implement evidence informed policies, which seek to manage the allocation of finite resources, in a context in which the decision making space is so extensively circumscribed by the decisions of the judiciary. Moreover, it is outside the remit of the $\mathrm{CC}$ to consider issues of financial sustainability when interpreting the Constitution and applying the rights of citizens to health services.

Arguably, the CC has been a driving force for social justice in a country in which other political institutions have often failed the population, and vulnerable or marginalized groups in particular. However, the almost continuous process of reform the health system has undergone since its creation points to the significant underlying issues which the government faces in securing the ongoing financial viability of the health service. Evidence informed policy-making offers a potential route for imposing limits on healthcare in a rational, equitable and legitimate manner. The ability of policies to be made in light of this evidence in an open and transparent manner in which decision makers can be held to account for their actions appears to be undermined by the judicialized nature of policymaking in Colombia. That said, the constitutional weaknesses and endemic corruption which has beset Congress means that there is no simple solution to the status quo. The reason the CC emerged as a powerful actor in health is due to the failure of the legislative-executive nexus. Recent attempts to institutionalize evidence use through semi-autonomous agencies such as IETS represent a clear attempt to develop new forms of evidence informed decision making. While this technocratic approach raises questions about democratic accountability, it offers a more effective means of ensuring EIPM and an efficient allocation of resources 
than the current reliance on the tutela mechanism and the outsourcing of policy decisions to the judiciary. 


\section{References}

ALEMANNO, A. (2013). The Emergence of the Evidence-Based Judicial Reflex: A Response to BarSiman-Tov's Semiprocedural Review. The Theory and Practice of Legislation, 1, 327-340.

BAR-SIMAN-TOV, I. (2016). The dual meaning of evidence-based judicial review of legislation. The Theory and Practice of Legislation, 1-27.

BARNES, A. \& PARKHURST, J. O. (2014). Can global health policy be depoliticised? A critique of global calls for evidence-based policy. In: YAMEY, G. \& BROWN, G. (eds.) Handbook of Global Health Policy. Wiley-Blackwell.

BEETHAM, D. (2013). The legitimation of power, Palgrave Macmillan.

BERNAL, O., FORERO, J. C., BARRERA, O. D., URUEÑA, R., VELASCO, N., AZUERO, F., . . RIVEROS, J. M. J. (Year) Published. The Judicialization of Health in Colombia. Proceedings in GV-Global Virtual Conference, 2013.

BERNAL, O., FORERO, J. C. \& FORDE, I. (2012). Colombia's response to healthcare crisis. Bmj, 344.

BIEHL, J., AMON, J. J., SOCAL, M. P. \& PETRYNA, A. (2012). Between the court and the clinic: lawsuits for medicines and the right to health in Brazil. Health Hum Rights, 14, E36-52.

BRINKS, D. M. \& FORBATH, W. (2014). The role of courts and constitutions in the new politics of welfare in Latin America. Law and Development of Middle-Income Countries, 221-45.

CASTRO, H. 2014. Assessing the Feasibility of Conducting and Using Health Technology Assessment in Colombia: The case of severe haemophilia A., London School of Hygiene and Tropical Medicine.

CEPEDA-ESPINOSA, M. J. (2004). Judicial activism in a violent context: The origin, role, and impact of the colombian constitutional court. Wash. U. Global Stud. L. Rev., 3, 529.

CHERNICHOVSKY, D., GUERRERO, R. \& MARTÍNEZ, G. (2012). The Incomplete Symphony: The Reform of Colombia's Healthcare System. Documentos de Trabajo PROESA.

CONTANDRIOPOULOS, D., LEMIRE, M., DENIS, J.-L. \& TREMBLAY, É. (2010). Knowledge Exchange Processes in Organizations and Policy Arenas: A Narrative Systematic Review of the Literature. Milbank Quarterly, 88, 444-483.

COUSO, J., HUNEEUS, A. \& SIEDER, R. (2010). Cultures of legality: judicialization and political activism in Latin America, Cambridge University Press.

DANIELS, N., CHARVEL, S., GELPI, A. H., PORTENY, T. \& URRUTIA, J. (2015). Role of the courts in the progressive realization of the right to health: between the threat and the promise of judicialization in Mexico. Health Systems \& Reform, 1, 229-234.

DANIELS, N. \& SABIN, J. E. (2008). Accountability for reasonableness: an update. BMJ: British Medical Journal, 337.

DARGENT, E. (2014). Technocracy and democracy in Latin America, Cambridge University Press.

DEFENSORIA DEL PUEBLO (2013). La Tutela y el Derecho a la Salud 2012, Bogota, Defensoria del Pueblo.

ESCOBAR, M.-L., GIEDION, U., GIUfFRIDA, A. \& GLASSMAN, A. L. (2009). Colombia: After a decade of health system reform. From Few to Many, 1.

FEDESAROLLO (2012). La Sostenibilidad Financiera del Sistema de Salud Colombiano: Dinámica del gasto y principales retos de cara al futuro. Bogotá, D.C.

FERRAZ, O. L. M. (2009). The right to health in the courts of Brazil: Worsening health inequities? Health and human rights, 33-45.

FIGUEIREDO, T. A., OSORIO-DE-CASTRO, C. G. S. \& PEPE, V. L. E. (2013). Evidence-based process for decision-making in the analysis of legal demands for medicines in Brazil. Cadernos de Saúde Pública, 29, s159-s166.

FRIEDMAN, A. (2008). Beyond accountability for reasonableness. Bioethics, 22, 101-112.

GARGARELLA, R. (2013). Latin American constitutionalism, 1810-2010: the engine room of the Constitution, Oxford University Press. 
GIEDION, U. \& URIBE, M. V. (2009). Colombia's universal health insurance system. Health Affairs, 28, 853-863.

GINSBURG, T. (2008). Judicialization of administrative governance: causes, consequences and limits. NTU L. Rev., 3, 1.

GLASSMAN, A. L., ESCOBAR, M. L., GIUFFRIDA, A. \& GIEDION, U. (2009). From few to many: ten years of health insurance expansion in Colombia, Inter-American Development Bank.

GONZÁLEZ-ROSSETTI, A. \& BOSSERT, T. J. (2000). Enhancing the political feasibility of health reform: A comparative analysis of Chile, Colombia, and Mexico. LAC HSR Health Sector Reform Initiative Paper.

GONZÁLEZ, A. C. \& DURÁN, J. (2011). Impact of court rulings on health care coverage: the case of HIV/AIDS in Colombia. MEDICC review, 13, 54-57.

HAWKINS, B. \& PARKHURST, J. (2016). The 'good governance' of evidence in health policy. Evidence \& Policy: A Journal of Research, Debate and Practice.

HERNÁNDEZ, M. (2005). Propuesta de reforma a la ley 100 de 1993. Opciones sociopolíticas en debate. Revista Gerencia y Política de Salud, 9, 180-90.

HERNÁNDEZ, M. \& TORRES-TOVAR, M. (2010). Nueva reforma en el sector salud en Colombia: portarse bien para la salud financiera del sistema. Medicina Social, 5, 241-245.

HIRSCHL, R. (2004). The political origins of the new constitutionalism. Indiana Journal of Global Legal Studies, 11, 71-108.

HIRSCHL, R. (2006). The new constitutionalism and the judicialization of pure politics worldwide. Fordham Law Review, 75, 721-754.

HIRSCHL, R. (2008a). The judicialization of mega-politics and the rise of political courts. Annual Review of Political Science, 11.

HIRSCHL, R. (2008b). The judicialization of politics. In: GREGORY A. CALDEIRA, R. D. K., AND KEITH E. WHITTINGTON (ed.) The Oxford Handbook of Law and Politics.

HOROWITZ, D. L. (1977a). The Courts and Social Policy (Washington, DC: Brookings Institution).

HOROWITZ, D. L. (1977b). The courts as guardians of the public interest. Public Administration Review, 37, 148-154.

INNVAER, S., VIST, G., TROMMALD, M. \& OXMAN, A. (2002a). Health policy-makers' perceptions of their use of evidence: a systematic review. Journal of Health Services Research and Policy, 7, 239-244.

INNVAER, S., VIST, G., TROMMALD, M. \& OXMAN, A. (2002b). Review article Health policy-makers' perceptions of their use of evidence : a systematic review. Policy, 7.

LANDAU, D. (2010). Political Institutions and Judicial Role in Comparative Constitutional Law. Harv. Int'I LJ, 51, 319.

LAVIS, J. N., OXMAN, A. D., MOYNIHAN, R. \& PAULSEN, E. J. (2008). Evidence-informed health policy 1 - synthesis of findings from a multi-method study of organizations that support the use of research evidence. Implementation science : IS, 3, 53-53.

LEONGOMEZ, E. P. (2006). Giants with feet of clay: Political parties in Colombia. The crisis of democratic representation in the Andes, 78.

LIZARAZO, A. \& LONDONO, J. (2009). La Reforma Política y Electoral en Colombia. In: ZOVATTO, D., AGUILAR, I. \& VIANELLO, L. C. (eds.) Experiencias de reforma política y electoral en Colombia, Costa Rica y México desde la perspectiva comparada latinoamericana. Costa Rica: IDEA Internacional.

LÓPEZ, C. \& SEVILLANO, Ó. (2008). Balance político de la parapolítica. Cor-65.

MENDES, C. (2013). Constitutional courts and deliberative democracy, Oxford University Press.

MENICUCCI, T. M. G. \& MACHADO, J. A. (2010). Judicialization of health policy in the definition of access to public goods: individual rights versus collective rights. Brazilian Political Science Review (Online), 5, 0-0.

MINISTERIO DE SALUD Y PROTECCIÓN SOCIAL (2015). Cifras financieras del sector salud: Recobros al FOSYGA por tecnologías en salud no incluídas en el plan de beneficios 2009-2014. [Online]. 
Available: https://www.minsalud.gov.co/sites/rid/Lists/BibliotecaDigital/RIDE/VP/FS/cifrasfinancieras-del-sector-salud\%20-boletin-numero-11.pdf [Accessed 7 December 2016].

MITTON, C., ADAIR, C. E., MCKENZIE, E., PATTEN, S. B. \& PERRY, B. W. (2007a). Knowledge Transfer and Exchange: Review and Synthesis of the Literature. Milbank Quarterly, 85, 729-768.

MITTON, C., ADAIR, C. E., MCKENZIE, E., PATTEN, S. B. \& WAYE PERRY, B. (2007b). Knowledge transfer and exchange: review and synthesis of the literature. The Milbank quarterly, 85 , $729-68$.

NUNES, R. M. (2010). Ideational origins of progressive judicial activism: The Colombian Constitutional Court and the right to health. Latin American Politics and Society, 52, 67-97.

NUTLEY, S. M., WALTER, I. \& DAVIES, H. T. O. (2007). Using evidence: how research can inform public services, Bristol, The Policy Press.

OECD (2013). Colombia: Implementing Good Governance [Online]. OECD. Available: http://dx.doi.org/10.1787/9789264202177-en [Accessed 17 August 2016].

OLIVER, K., INNVAR, S., LORENC, T., WOODMAN, J. \& THOMAS, J. (2014). A systematic review of barriers to and facilitators of the use of evidence by policymakers. BMC Health Services Research, 14, 2.

OXMAN, A. D., LAVIS, J. N., LEWIN, S. \& FRETHEIM, A. (2009). SUPPORT Tools for evidence-informed health Policymaking (STP) 1: What is evidence-informed policymaking? Health Research Policy and Systems, 7, S1.

PETERSEN, N. (2013). Avoiding the common-wisdom fallacy: The role of social sciences in constitutional adjudication. International journal of constitutional law, 11, 294-318.

RIOS-FIGUEROA, J. \& TAYLOR, M. M. (2006). Institutional determinants of the judicialisation of policy in Brazil and Mexico. Journal of Latin American Studies, 38, 739.

RODRÍGUEZ GARAVITO, C. (2012). La judicialización de la salud: síntomas, diagnóstico y prescripciones. In: BERNAL, O. \& GUTIERREZ, C. (eds.) La Salud en Colombia. Logros, Retos y Recomendaciones, Bogotá. Bogota: Universidad de Los Andes.

RYAN, D. (Year) Published. Democratic Governance and the Judicialization of Policy: A Qualitative Comparative Analysis of Policy Conflicts in Argentina. APSA 2010 Annual Meeting Paper, 2010.

SAAVEDRA-HERRERA, C. E. 2013. Democracy, judicialisation and the emergence of the Supreme Court as a policy-maker in Mexico. London School of Economics.

SACKETT, D. L., ROSENBERG, W. M., GRAY, J. M., HAYNES, R. B. \& RICHARDSON, W. S. (1996). Evidence based medicine: what it is and what it isn't. British Medical Journal Publishing Group.

SCRIBNER, D. L. (2010). The Judicialization of (Separation of Powers) Politics: Lessons from Chile. Journal of Politics in Latin America, 2, 71-97.

SHAXSON, L., BIELAK, A. \& AL, E. (2012). Expanding our understanding of $K^{*}$ (KT, KE, KTT, KMb, KB, $K M$, etc.).

SIEDER, R., SCHJOLDEN, L. \& ANGELL, A. (2005). The judicialization of politics in Latin America, Springer.

STONE, D. A. (1997). Policy paradox: The art of political decision making, WW Norton New York.

TSEBELIS, G. (2002). Veto players: How political institutions work, Princeton University Press.

UPRIMNY, R. \& DURÁN, J. (2014). Equidad y protección judicial del derecho a la salud en Colombia [Online]. Available:

http://www.cepal.org/publicaciones/xml/3/53503/EquidadyproteccionjudicialCOLOMBIA.pd f.

UPRIMNY, Y. R. (2007). Judicialization of Politics in Colombia: Cases, Merits and Risks. Sur-Revista Internacional de Derechos Humanos, 3, 53-69.

VALE, H. F. D. (2013). The judicialization of territorial politics in Brazil, Colombia and Spain. Brazilian Political Science Review, 7, 88-113.

VALLINDER, T. \& TATE, C. N. (1995). Global Expansion of Judicial Power, New York University Press. 
VARGAS-PELÁEZ, C. M., ROVER, M. R. M., LEITE, S. N., BUENAVENTURA, F. R. \& FARIAS, M. R. (2014). Right to health, essential medicines, and lawsuits for access to medicines-A scoping study. Social Science \& Medicine, 121, 48-55.

WALTER, I., NUTLEY, S. \& DAVIES, H. (2005). What works to promote evidence-based practice? A cross-sector review. Evidence \& Policy: A Journal of Research, Debate and Practice, 1, 335364.

WANG, D. W. (2013). Courts and health care rationing: the case of the Brazilian Federal Supreme Court. Health Economics, Policy and Law, 8, 75-93.

WEISS, C. H. (1979). The many meanings of research utilization. Public administration review, 39, 426-431.

YAMIN, A. (2014). Promoting equity in health: What role for courts? Health \& Human Rights, 16.

YAMIN, A. E. \& PARRA-VERA, O. (2009). How do courts set health policy? The case of the Colombian Constitutional Court. PLoS Medicine, 6, 147.

YAMIN, A. E. \& PARRA-VERA, O. (2010). Judicial protection of the right to health in Colombia: From social demands to individual claims to public debates. Hastings Int'l \& Comp. L. Rev., 33, 431. 